\title{
Philanthrocapitalism: Reflections on Politics and Policy Making
}

\author{
Kavita N. Ramdas
}

Published online: 2 August 2011

(C) Springer Science + Business Media, LLC 2011

Recently, Bill and Melinda Gates were in my homeland, India, meeting with the richest men (and they are all men, so far) of the Indian elite. They were seeking to persuade Indian billionaires to join an elite international club-the philanthro-capitalists who have taken the "giving pledge"a pledge to give at least half their wealth to charity in their lifetime or at the time of their death. I do hope that they succeed and I would be delighted to learn that Ratan Tata, Mukesh Ambani and Lakshmi Mittal had decided to make their contributions to philanthropic causes benefiting those less fortunate than themselves. It would certainly sit easier with most Indian citizens than watching another 27 storey single family home being built in Mumbai with a helipad and a rooftop swimming pool. (Mukesh Ambani recently built a 27 storey single family home in Mumbai.)

My concern, however, is that far too few in this elite club are willing to ask themselves hard questions about a model of economic growth that has made their phenomenal acquisition of wealth possible in a nation where over 800 million people still languish in poverty and that is home to the largest number of malnourished children. Data from McKinsey \& Co. show that the number of households in the highest-earning income bracket, making more than $\$ 34,000$ a year, has risen to 2.5 million, from 1 million in 2005. But the ranks of those at the bottom, making less than $\$ 3,000$ a year, also have grown, to 111 million, from 101 million in 2005. In fact, as a recent article in the Wall Street Journal (March 30, 2011, "In India, Doubts Gather Over Rising Giant's Course") suggests, it may be precisely the

K. N. Ramdas $(\square)$

CDDRL/PACS, Freeman Spogli Institute,

E 109, Encina Hall,

Stanford, CA 94305, USA

e-mail: knramdas@stanford.edu same factors that helped create the billionaires that have also exacerbated social injustice and inequality, malnutrition, and disempowerment for millions of poor people across India.

Social change philanthropy, in contrast to traditional charity, must be measured by its capacity to question the dominant development model, to seek the root causes of inequality, and to engage in a process of self-reflection that also seeks to expand its accountability to the broader public that it seeks to serve. Only then, can private or public philanthropy realize its potential as a genuine catalyst for transformative social change. In my experience, while there certainly are foundations and individual donors who are willing to engage in a more self-critical analysis and open themselves to greater public scrutiny, the dominant form of global philanthrocapitalism, is far too deeply embedded in the current economic and political status quo of global capitalism, to make investments that might really rock the boat. At the same time, much to my relief, citizen-led social justice movements around the globe are emerging to challenge the substance, form, and direction of philanthrocapitalism as well as the current, largely unequal systems of trade and global capitalism.

Robin Rogers argues that we should consider the Gates' giving pledge a manifestation of philanthrocapitalism, while the creation of the "Good Club", the group of the world's wealthiest individuals who have agreed to engage in setting an agenda to improve the world, is what she terms philanthro-policymaking. Her article suggests that the critics of philanthrocapitalism are not really against the use of those funds for the social good, but rather are opposed to the policymaking and agenda setting powers of the new global elite. She goes on to suggest that there truly are impressive resources that might be brought to bear on the world's most pressing problems by the new philanthro- 
capitalists and that we might be able to reconcile contemporary critics of philanthrocapitalism with their admiring supporters, if we could develop mechanisms by which we might hold the "super elite" accountable. Her recommendation for how we might do so, relies on her confidence that "A capitalist economy within a functioning democracy, in my view is the best system that humanity has achieved to date." She urges us to explore ways to extend democratic practices that enable a process by which the disproportionate powers of this elite are held in check by a new system of accountability. She envisions this system as being capable of managing a civil discourse between government and philanthropy. And, finally, she outlines some examples of what she sees as the beginnings of a new infrastructure for philanthrocapitalism.

I believe that Roger's position is certainly optimistic, but is becoming increasingly less likely, particularly in the context of a United States in which the Supreme Court has effectively voted to allow corporations and other interest groups to buy almost every vote of every member of the Congress and Senate. Democracy does not seem to have made elites more accountable in the United States where income inequality now stands at the highest levels since the end of the cold war. My position on these matters is informed by Michael Edwards, who challenged the basic premise underlying the highly hyped phenomena of "philanthrocapitalism" (Michael Edwards, Just Another Emperor: The Myths and Realities of Philanthrocapitalism, Demos, 2008).

First outlined by Matthew Bishop in his 2006 Economist article, "the birth of philanthrocapitalism", this perspective was further developed with Michael Green in a book immodestly entitled, "How the Rich can Save the World." Bishop and Green argued that the practices of markets and business were inherently superior to those of the non-profit sector and government. Ironically, despite the continuing recession and 3 years of global financial crisis brought about primarily by unregulated and unethical business practices in the financial sector, the allegedly "inherently superior" dynamics of the private sector are now being promoted by a Tea Party dominated Congress in the United States.

In contrast, Edwards argues that while philanthrocapitalism (using business practices, tools and market forces to advance the greater social good) might marginally succeed at increasing access to socially beneficial goods and servicessuch as seeds, malaria nets and vaccines - it is likely to be "profoundly insufficient to level deeper changes in the distribution of power and resources across the world." In particular, he notes that that the most impressive social transformations in recent history-the women's movement, the civil rights movement, the anti-apartheid movement in South Africa, have been the result of complex interactions between social movements, politics, and the state.
As someone who grew up in India, and has worked for many years in both private and public foundations, most recently as the CEO of the Global Fund for Women, I am skeptical about what is likely to change as a result of philanthrocapitalism's focus on Money, Markets, Measurement and Management. I am troubled by the hubris that often seems to lurk just below the surface of the good citizen conscience of the very wealthy and increasingly unnerved by the alignment of fashion, power and celebrity behind it. But where is the evidence that "philanthrocapitalism" works, and are there better ways to achieve urgently needed global social progress?

In some ways the new philanthrocapitalism or venture philanthropy can be seen as a natural extension of the pattern that saw a triumphant western capitalism assuming its undisputed place as the dominant global economic system after the collapse of the Soviet Union and the demise of socialism or communism as a feasible alternative economic system. Despite many good intentions, this version of philanthropy seems poorly suited to resolve the world's most deep-rooted problems.

This is because it is enmeshed in two contradictions. The first is, that the more unequal the world gets, the more the public is being invited to celebrate a cherished few who benefit from this condition of inequality. Indeed, we pour adulation on the those among this new super elite who have chosen to use some of their almost unfathomable wealth to address "specific" problems with "measurable" outcomes. Half of Warren Buffet's net worth would still leave him with $\$ 25$ billion. What is missing in most discussions of the new mega-philanthropy is any deeper questioning about what ails a global economic system that seems to produce endemic inequality, crushing poverty, and food insecurity - all of which damage the livelihoods of hundreds of millions of people. The new philanthropy avoids exploring what is wrong at this systemic levelwhere a single individual's net worth can become larger than the combined GDPs of some of the world's poorest nations.

The second contradiction is that even as the significant downsides of so-called "development" in the global north become ever clearer (among them growing inequality, unsustainable consumption patterns, financial freefall caused by lack of regulation, banking structures that favor a super elite, and the onset of severe lifestyle-related health problems), philanthrocapitalism in its current form seeks to invest in efforts and initiatives that can bring the wonders of this model of development to people and communities around the globe. Remarkably, the more the West learns about the drawbacks of industrial agriculture, excessive dependence on fossil fuels, the fallibility of nuclear power, and the poor health outcomes related to current sedentary forms of life, the more it seems determined to share its 
successful development strategies with the so-called "developing world". Yet, as our world grows ever more interdependent $-a$ fact that global climate change is making clear-communities and social movements across the world are seriously questioning the assumptions that underlie this new version of the "white man's burden" or the view that "we" know what is best for "you".

\section{The Wrong Fix}

It is vital to examine the actual effects of this form of "development". Vandana Shiva has written: "Development deprives the very people it professes to help of their traditional land and means of sustenance, forcing them to survive in an increasingly eroded natural world. The reality is that people do not die for lack of income. They die for lack of access to the wealth of the commons." Some striking examples internationally include:

- the combination of "free-market" policies and the removal of government subsidies that is putting intense pressure on Indian small farmers and peasants, causing them to lose the equivalent of $\$ 26$ billion dollars annually, and leading to over 5,000 farmer suicides in 2007 alone;

- water, an essential resource for life, is now a $\$ 400$ billion dollar industry controlled mainly by western corporations, who now profit by selling a resource to the poor that was once free;

- the approximately $\$ 50$ billion dollars of "aid" (including private philanthropy) trickling from global north to global south is but a tenth of the $\$ 500$ billion dollars being sucked out of the global south each year in the form of interest payments on loans and other mechanisms imposed by international financial agencies, including the World Bank and the IMF.

These realities notwithstanding, there is little, if any, evidence that "philanthrocapitalism" is interested in looking at such structural realities, or examining the root causes of current economic or political inequality and injustice. Indeed, Nobel laureates Amartya Sen and Joseph Stiglitz argue that the developing world's most pressing problems could most effectively be solved by changing the terms of political and economic power within the current system. Amartya Sen upset the Indian ruling class recently with his blunt pronouncement that, "while economic growth is an important boon for enhancing living conditions, its reach depends greatly on what we do with the fruits of growth." He went on to add, "perhaps more worryingly, this group of relatively privileged and increasingly prosperous Indians can easily fall for the temptation to treat economic growth as an end in itself, for it serves directly as the means of their opulence and improving lifestyles without further social efforts. The insularity that this limited perspective generates can even take the form of ridiculing social activists - who keep reminding others about the predicament of the larger masses of people who make up this great country. The fact is, however, that India cannot be seen as doing splendidly if a great many Indians - sometimes most Indians - are having very little improvement in their deprived lives."

The new philanthropy is nowhere near resolving the dilemma posed by Vandana Shiva that "it may not be about how much wealthy nations and individuals can give, so much as how much less they can take. Current philanthropic practice seems motivated by technological solutions, the same "fix-the-problem" mentality that allowed business people to succeed as hedge-fund managers, capital- market investors, or software-developers. This approach is designed to yield measurable and fairly quick solutions. A symptom of this may be found in the kind of skills that new foundations are seeking. I am struck by how few social scientists are employed at the new "mega-philanthropies". Instead, the people most sought after are management consultants, business people, former industry leaders or lobbyists, and scientists. Each of these is expected to bring a crisp and coolly efficient approach to their work, demonstrating their "expertise" on specific issues - climate change, agricultural productivity, soil quality, or infectious disease. The nuance and inherent humility of the social sciences - the realization that development has to do with people, with human and social complexity, with cultural and traditional realities, and their willingness to struggle with the messy and multifaceted aspects of a problem - have no cachet in this metrics-driven, efficiency seeking, technology focused approach to social change.

\section{The Seeds of Change}

Even the complex issue of "gender" has been neatly broken down into clear and water-tight compartments with specific goals - ending maternal mortality, educating girls, increasing the incomes of women. Yet, if you speak with the creative social activists on the ground in countries around the world, you will hear that they have become wary of the term "invest in women", because they see the language of economic profit appropriating a much richer and multi-hued landscape relating to women's status and position in their families and communities.

Feminists and women's rights activists have struggled for decades to explain that women's rights live in the murky, unclear, and constantly shifting intersections between economic inequalities, discriminatory traditional and cultural practices, political and personal lack of power, and violence- 
in the home, in intimate relationships, and on the streets and battlefields. For this reason, women's funds, both in the United States and abroad, emerged as a counter to mainstream foundations. Women's foundations sought to support women's own articulations of their struggle for justice and equality by working at various levels and within all the structures where women and girls are systematically disempowered. (See Women's Funding Network for a list of US and international women's funds www.wfn.org.) Yet, as we seek to survive in the constant competitive fundraising environment, we often find ourselves struggling for ways to "sell" our model to new investors - even as we hope it may have the capacity to influence or at least challenge the dominant and far more affluent model of most philanthro-capitalists.

Many of us working in philanthropy are increasingly concerned by the tendency to "follow the money". This holds equally true for smaller and older private or family foundations,many of whom did have a strong social justice lens in years past. Many are now desperately seeking to be viewed as relevant and competitive in a world where they have been dwarfed by the mega-funds of Gates and Buffet or potential philanthropy/business hybrids emerging out of corporations like Nike, Google and Facebook. Yet, as Michael Edwards correctly points out, those of us who have been social-justice advocates and activists before we became "professional non-profit leaders" know all too well that it is social movements and their ability to hold both governments and the private sector accountable, that are truly going to change our world (Colin Greer of the New World Foundation echoes this argument in his article, "Philanthropy as solidarity" [21 April 2008]). So, even as we seek to figure out how to raise next year's budget and which new foundations we will pursue (in the case of public foundations) or how we can engage in partnerships with Gates and Buffet (in the case of many private foundations), we simultaneously fill our strategic plans with pledges and commitments to be engaged in movement-building. Indeed, movement-building has become the new buzz-word among foundations, nonprofits, and global NGOs.

\section{A New Dialogue}

So, where does this leave us? What should we make of Audre Lorde's words: "you cannot use the master's tools to dismantle the master's house," or as others have said even more bluntly, "the revolution will not be funded." Is there a third way? Can we engage in shared debate and discussion and learning that fully confronts the contradictions that I outlined at the beginning of this analysis? I believe it is time for forward-thinking social change philanthropists to dialogue with both social activists and philanthro-capitalists.

In our own work, we can use our smaller more flexible funds to seed, strengthen, and link activists who might help to develop a new cross-sector partnership. Such a partnership should be able to connect those of us who work in philanthropy with one another, with those in the socialbenefit sector, in the private sector, and in government. Such a partnership would need to begin with a shared sense that the tools we have been using so far are simply not enough-not in a world that has just witnessed the extraordinary people's revolutions in Tunisia and Egypt and the stirrings of an Arab spring across many other countries in the Middle East. It will require us to demonstrate a collective willingness to unpack what has and has not worked as philanthropy has sought to mitigate, alleviate, or take advantage of the rapid changes that have occurred under the broad rubric of "globalization" and "economic growth" over the past twenty years.

In this effort, both philanthro-capitalists and old time philanthropists could benefit from listening to and learning from those on the ground who are working in some of the most exciting social-justice movements around the globe. The proposition that business does not, after all, have all the answers, and that the social-benefit sector, particularly people's movements, have much knowledge and substance to share, would be an excellent starting-point for a dialogue. (See Karen Weisblatt, "Individual giving, collective action", Open Democracy, 23 April 2008.)

From there, we can begin also to re-engage the state and governments, in a conversation based on mutual respect and a genuine willingness to learn from one another. Failing such openness on the part of the philanthropic sector, we may well find that this greater transparency, dialogue and accountability will be forced on all philanthropists by the growing pressure from the street, where the multiple constituencies that philanthropy claims to serve, are beginning to find the confidence and courage to make their voices heard.

Kavita N. Ramdas, a Visiting Scholar at Stanford University's Center for Democracy, Development and Rule of Law, was most recently president and chief executive officer at the Global Fund for Women where she currently serves as a senior advisor. 